\title{
Pengaruh Problem Based Learning dan Group Investigation Terhadap Prestasi Belajar IPA Ditinjau dari Kecerdasan Interpersonal Siswa Kelas V SDN Sedabin Diponegoro
}

\author{
Ferawati L4 ${ }^{4}$ Budiyono 5 , Sri Yutmini 6 \\ akhwatvisioner89@gmail.com
}

\begin{abstract}
Abstrak: Penelitian ini bertujuan untuk mengetahui: (1) perbedaan pengaruh pembelajaran Problem Based Learning dan Group Investigation terhadap prestasi belajar IPA, (2) perbedaan pengaruh yang signifikan antara siswa yang memiliki kecerdasan interpersonal tinggi dan rendah terhadap prestasi belajar IPA, (3) interaksi pengaruh antara model pembelajaran dan kecerdasan interpersonal siswa terhadap prestasi belajar IPA. Penelitian ini merupakan penelitian kuantitatif. Metode yang digunakan adalah eksperimen. Populasi dari penelitian ini adalah seluruh siswa kelas V di SDN dabin Diponegoro Ngringo Jaten Karanganyar tahun pelajaran 2013/ 2014. Pengambilan sampel dilakukan dengan cluster random sampling, sampel dalam penelitian ini adalah SDN 04 Ngringo sebagai kelompok eksperimen dan SDN 07 Ngringo sebagai kelompok kontrol. Teknik pengumpulan data adalah tes prestasi belajar IPA dan angket kecerdasan interpersonal. Ujicoba instrumen tes meliputi validitas isi, tingkat kesukaran, dan reliabilitas. Ujicoba intrumen angket meliputi validitas isi dan reliabilitas. Uji prasyarat meliputi uji normalitas, uji homogenitas, dan uji kesetaraan. Uji hipotesis dengan uji anava dua jalan dengan sel tak sama. Hasil penelitian menunjukkan: (1) terdapat perbedaan pengaruh antara pembelajaran Problem Based Learning dan Group Investigation dalam menghasilkan prestasi belajar IPA. Hasil penelitian menunjukkan $F_{a}=15.68$ dengan $F_{\text {tabe }}=7.31$, keputusan uji $H_{0 A}$ ditolak. (2) tidak terdapat perbedaan pengaruh yang signifikan antara siswa yang memiliki kecerdasan interpersonal tinggi dan kecerdasan interpersonal rendah dalam menghasilkan prestasi belajar IPA. Hasil penelitian menunjukkan $F_{b}=0.59$ dengan $F_{\text {tabel }}=7.31$, keputusan uji $H_{0 B}$ diterima. (3) tidak terdapat interaksi pengaruh antara model pem-belajaran dan kecerdasan interpersonal siswa terhadap prestasi belajar IPA. Hasil penelitian menunjukkan $F_{c}=0.036$ dengan $F_{\text {tabel }}=7.31$, keputusan uji $H_{0 A B}$ diterima.
\end{abstract}

Kata kunci: Problem Based Learning, Group Investigation, Prestasi belajar IPA, Kecerdasan interpersonal.

\footnotetext{
${ }^{4}$ Alumni Magister Teknologi Pendidikan Universitas Sebelas Maret Surakarta

${ }^{5}$ Dosen Universitas Sebelas Maret Surakarta

${ }^{6}$ Dosen Universitas Sebelas Maret Surakarta
} 


\section{PENDAHULUAN}

enelitian ini dilatarbelakangi oleh proses belajar sepanjang hayat. Dimana belajar merupakan proses yang terjadi pada diri setiap manusia sejak dia lahir sampai meninggal dunia. Konsep belajar sepanjang hayat menjadikan peserta didik harus dipersiapkan untuk menjadi pebelajar sepanjang hayat (life long learner). Menurut Anitah (2009) dalam belajar tidak hanya peserta didik saja yang diharapkan dapat belajar sepanjang hayat tetapi gurupun dituntut hal yang demikian pula, agar ilmunya tidak tertinggal jauh dengan peserta didiknya.

Adapun tujuan dari penelitian ini bertujuan untuk mengetahui: (1) perbedaan pengaruh pembelajaran Problem Based Learning dan Group Investigation terhadap prestasi belajar IPA, (2) perbedaan pengaruh yang signifikan antara siswa yang memiliki kecerdasan interpersonal tinggi dan rendah terhadap prestasi belajar IPA, (3) interaksi pengaruh antara model pembelajaran dan kecerdasan interpersonal siswa terhadap prestasi belajar IPA.

Azwar (2013) menegaskan bahwasannya prestasi belajar atau keberhasilan belajar merupakan hasil belajar peserta didik yang dapat dioperasionalkan dalam bentuk indikator-indikator yang berupa nilai rapor, indeks prestasi studi, angka kelulusan, predikat keberhasilan, dan semacamnya. Prestasi belajar di sini dianggap sebagai keberhasilan belajar. Belajar sebagai perubahan perilaku yang diakibatkan pengalaman atau sebagai hasil interaksi individu dengan lingkungannya. Azwar (2013) menganggap karena sifat manusia bersifat dinamis dan terbuka terhadap berbagai bentuk perubahan yang dapat terjadi pada dirinya dan pada lingkungan sekitarnya maka proses belajar akan selalu terjadi tanpa henti dalam kehidupan manusia. Dalam pandangan psikologi kognitif, proses belajar bahkan terjadi secara otomatis tanpa memerlukan adanya motivasi.

Menurut Winkel (Purwanto, 2009) hasil belajar merupakan perubahan yang mengkibatkan manusia berubah dalam sikap dan tingkah lakunya. Keberhasilan belajar pada diri peserta didik atau prestasi belajar ini dapat dinilai dari perubahan yang terjadi baik dari segi pengetahuan yang dibangunnya setelah proses belajar itu sendiri, se-bagai hasil perolehan peserta didik dalam belajar (kognitif), serta dapat dilihat dari sikap yang dibentuknya setelah proses belajar itu berlangsung (afektif), serta dari perubahan perilaku yang tercermin sebagai bentuk kemampuan dan kecakapan diri peserta didik dalam penguatan ketrampilan baru yang dimilikinya (psikomotor).

Jika prestasi merupakan keberhasilan belajar, maka dapat diartikan bahwa hasil belajar dan prestasi belajar itu merupakan hal yang sama. Gagne (Purwanto, 2009) menegaskan bahwa hasil belajar merupakan terbentuknya konsep, yaitu kategori yang kita berikan pada stimulus yang ada di lingkungan, yang menyediakan skema yang terorganisasi untuk mengasimilasi stimulus-stimulus baru dan menentukan hubungan di dalam dan di antara kategori-kategori.

Prestasi belajar IPA merupakan penilaian guru terhadap keberhasilan belajar peserta didiknya dalam memperoleh pengalaman belajar mengenai kospep ilmu pengetahuan alam atau sains yang diwujudkan dalam simbol, baik yang berupa huruf atau angka yang dilakukan secara bertahap sesuai dengan standar kompetensi dan kompetensi dasar yang tersusun dalam kurikulum, penilaian ini bertujuan untuk mengoptimalkan kemampuan peserta didik untuk belajar tentang alam dan sekitarnya, kemudian mengaktualisasikan pengetahuannya ini untuk diterapkan dalam kehidupan sehari-hari.

Menurut Azwar (2013) keberhasilan dalam belajar dipengaruhi oleh banyak faktor yang bersumber dari dalam (internal) maupun faktor yang bersumber dari luar (eksternal) pada diri peserta didik. Hal ini perlu diperhatikan guru dalam mengoptimalkan proses pembelajaran baik di kelas maupun di luar kelas. Pembelajaran yang optimal diharapkan mampu menciptakan keberhasilan belajar bagi peserta didik yang optimal pula.

Menurut Joyce (Sugiyanto, 2009) model pembelajaran merupakan perencanaan atau suatu pola yang digunakan sebagai pedoman dalam merencanakan pembelajaran di kelas atau pembelajaran dalam tutorial. Model pembelajaran digunakan sebagai pedoman untuk menentukan perangkat- 
perangkat pembelajaran baik buku-buku, film, komputer, maupun kurikulum dalam pencapaian tujuan pembelajaran.

Menurut Trianto (2007) model pembelajaran bermakna lebih luas daripada strategi, metode ataupun prosedur. Model pembelajaran mempunyai empat ciri khusus yang akan membedakan dengan straregi, model atapun prosedur pembelajaran. Model pembelajaran memiliki ciri meliputi: (1) rasional teoritik logis yang disusun oleh para pencipta atau pengembangnya, (2) landasan pemikiran tentang apa dan bagaimana peserta didik itu belajar, (3) tingkah laku mengajar yang dipperlukan agar model tersebut dapat dilaksanakan dengan berhasil, serta (4) lingkungan belajar yang diperlukan agar tujuan pembelajaran itu dapat tecapai.

Menurut Trianto (2009) model pembelajaran memiliki ciri-ciri khusus yang dapat membedakan antara strategi pembelajaran, metode pembelajaran, teknik pembelajaran, bahkan prosedur pembelajaran. Menurut Nieveen (Trianto, 2009), model pembelajaran dapat dikatakan baik apabila memenuhi berbagai macam kriteria berikut, yaitu: (1) shahih (valid); yakni apakah model yang dikembangkan didasarkan pada rasional teoritik yang kuat dan apakah terdapat konsistensi internal, (2) praktis; yakni dipenuhi jika para ahli dan praktisi menyatakan bahwa apa yang dikembangkan dapat diterima dan pada kenyataannya menunjukkan apa yang dikembangkan dapat diterapkan, (3) efektif; yakni berkaitan dengan ahli dan praktisi yang berdasarkan pengalamannya menyatakan bahwa model tersebut dikatakan efektif dan secara operasional model tersebut memberikan hasil sesuai dengan yang diharapkan.

Menurut Sugiyanto (2009) Problem Based Learning atau PBL mengambil psikologi kognitif sebagai dukungan teoritisnya. Fokus utama PBL tidk banyak pada apa yang sedang dikerjakan peserta didik (perilaku peserta didik), namun lebih menekankan kepada apa yang dipikirkan oleh peserta didik (tingkat kognisi peserta didik) selama melaksanakan kegiatan pembelajaran dengan model pembelajaran Problem Based Learning ini.

Mudjiman (2011) berpendapat bahwa PBL merupakan model pembelajaran yang melatih kemampuan memecahkan masalah melalui langkah-langkah sistematis. Siswa membentuk pengetahuan baru melalui langkah analisis terhadap pengetahuan-pengetahuan baru yang mereka kumpulkan. Siswa menganalisis sebuah masalah kemudian menkonstruksikannya menjadi pengalaman baru.

Karakteristik dari model pembelajaran Problem Based Learning mempunyai tiga tingkatan: (1) prinsip teori belajar terpusat, dimana yang menjadi pusat perhatian dalam model pembelajaran PBL adalah peserta didik memiliki motivasi yang tinggi untuk belajar mandiri, (2) spesifikasi model pembelajaran ini berbasis kepada peberian masalah, (3) praktik terpenting berpedoman pada model pembelajaran tradisional.

Segers, dkk (2003) merumuskan mengenai The Seven-Jump Procedure in Problem Based Learning: (1) understand all terms, (2) define the problem, (3) analyse the problem (Brainstorm: activate prior knowledge, discuss), (4) synthesize (arrange ideas), (5) define learning objectives, (5) self-study, (6) report back.

Keuntungan pemanfaatan model pembelajaran Problem Based Learning menurut Anitah (2009) antara lain: (1) memandu peserta didik dalam belajar, (2) memadukan materi pembelajaran sehingga pemahaman peserta didik akan lebih komprehensif, (3) memberikan perspektif yang berbeda pada tingkat pengetahuan peserta didik, serta (4) mengajarkan keterampilan memecahkan masalah.

Menurut Sharan and Sharan (Slavin, 2005) merupakan sebuah model pembelajaran yang berawal dari perencanaan pengaturan kelas umum di mana para siswa bekerja dalam kelompok kecil menggunakan pertanyaan kooperatif, diskusi kelompok, serta perencanaan dan proyek kooperatif. 
Menurut Trianto (2007) model pembelajaran Group Investigation membagi kelas menjadi beberapa kelompok yang terdiri dari 5-6 peserta didik yang heterogen, dimana pembagian peserta didik ini dibentuk berdasarkn pertimbangan keakraban persahabatan atau minat yang sama dengan topik tertentu. Kemudian peserta didik memilih topik untuk diselidiki dan melkukan penyelidikan yang mendlaam atas topik yang telah dipilih, lalu menyiapkan dan mempresentasikan laporannya kepada seluruh kelas.

Menurut Yaumi (Brainbridge, 2010) kecerdasan dianggap sebagai kemampuan mental umum untuk belajar dan menerapkan pengetahuan dalam memanipulasi lingkungan, serta kemampuan untuk berpikir abstrak. Definisi tersebut mengandung pengertian bahwasannya kecerdasan mencakup kemampuan beradaptasi dengan lingkungan baru atau perubahan lingkungan saat ini, kemampuan untuk mengevaluasi dan menilai, kemampuan untuk memahami ide-ide yang kompleks, kemampuan untuk berpikir produktif, kemampuan untuk belajar dengan cepat, belajar dari pengalaman dan bahkan kemampuan untuk memahami hubungan.

Kecerdasan manusia dilihat dari tiga komponen (Yaumi, 2012) yakni: (1) kemampuan untuk mengarahkan pikiran dan tindakan, (2) kemampuan untuk mengubah arah pikiran atau tindakan, san (3) kemampuan untuk mengkritik pikiran dan tindakan sendiri. Gardner membagi kecer-dasan jamak itu menjadi delapan macam kecerdasan, yakni: (1) kecerdasan verbal-linguistik, (2) logis-matematis, (3) visual-spasial, (4) berirama-musik, (5) jasmaniyah-kinestetik, (6) interpersonal, (7) intrapersonal, dan (8) naturalistik.

Menurut Yaumi (2012) kecerdasan interpersonal sangat berhubungan dengan konsep interaksi dengan orang lain di sekitar. Interaksi yang dimaksud bukan hanya sekedar berhubungan biasa saja seperti berdiskusi dan membagi suka dan duka, melainkan juga memahami pikiran, perasaan dan kemampuan untuk memberikan impati dan respon. Biasanya orang yang memiliki kecerdasan interpersonal tinggi ini memiliki sikap sangat sensitif terhadap suasana hati dan perasaan orang lain.

Empat elemen penting menurut Yaumi (Mork, 2011) dari kecerdasan interpersonal yang perlu digunakan dalam membangun komunikasi, mencakup: (1) membaca isyarat sosial, (2) memberikan empati, (3) mengontrol emosi, serta (4) mengekspresikan emosi pada tempatnya.

Adapun hipotesis dalam penelitian ini adalah: (1) terdapat perbedaan pengaruh yang signifikan antara model pembelajaran Problem Based Learning dan Group Investigation terhadap prestasi belajar IPA, (2) terdapat perbedaan pengaruh yang signifikan antara siswa yang memiliki kecerdasan interpersonal tinggi dan rendah terhadap prestasi belajar IPA, (3) terdapat interaksi pengaruh yang signifikan antara model pembelajaran Problem Based Learningdan Group Investigation dan kecerdasan interpersonal tinggi dan rendah terhadap prestasi belajar IPA.

\section{METODE PENELITIAN}

Jenis penelitian ini merupakan penelitian eksperimen, menurut Sugiyanto (2013), penelitian eskperimen merupakan penelitian yang digunakan untuk mencari pengaruh perlakuan tertentu terhadap yang lain dalamkondisi yang dikendalikan.

Penelitian ini berlokasi di sekolah dasar negeri sedabin Diponegoro Ngringo Jaten Karanganyar pada tahun pelajaran 2013/ 2014. Dengan waktu penelitian sejak bulan November 2013 s.d. Juli 2014. Adapun rancangan penelitian adalah dengan desain faktorial $2 \times 2$, dimana penelitian ini membandingakn dua model pembelajaran yakni model pembelajaran Problem Based Learning dan Group Investigation, dan dua kecerdasan interpersonal yakni kecerdasan interpersonal tinggi dan kecerdasan interpersonal rendah.

Populasi dalam penelitian ini adalah seluruh siswa kelas V di Sekolah Dasar Negeri sedabin Diponegoro tahun pelajaran 2013/2014. Selanjutnya teknik pengambilan sampel adalah dengan cluster 
random sampling, dimana sampel kelompok eksperimen adalah SDN 04 Ngringo dan kelompok kontrolnya adalah SDN 07 Ngringo.

Sumber data dalam penelitian ini adalah prestasi belajar IPA siswa pada semester sebelumnya yang digunakan sebagai data awal dalam penelitian. Adapun teknik pengumpulan datanya adalah dengan metode tes dan metode angket. Instrumen penelitiannya terdiri dari: (1) instrumen tes prestasi belajar IPA, dan (2) instrumen angket kecerdasan interpersonal.

Teknik analisis datanya dengan anava dua jalan dengan sel tak sama. Adapun uji prasyarat analisisnya terdiri dari tiga hal yakni uji normalitas, uji homogenitas, dan uji kesetaraan.

\section{HASIL DAN PEMBAHASAN}

\section{Hasil Penelitian}

Hasil uji anava dua jalan adalah sebagai berikut:

Nilai $F_{a}$ sebesar 15.68 dengan daerah kritis 7.31. $F_{a}$ terletak pada daerah kritis sehingga $\mathrm{H}_{0}$ ditolak yang artinya terdapat perbedaan pengaruh yang signifikan antara model pembelajaran Problem Based Learning dan Group Investigation terhadap prestasi belajar IPA. Ditolaknya $\mathrm{H}_{0}$ mengindikasikan bahwa antara Problem Based Learning dan Group Investigation memberikan efek yang tidak sama dalam efektifitas terhadap prestasi belajar IPA. Dengan melihat rerata prestasi belajar IPA antara kedua model ini diketahui bahwa rerata model pembelajaran Problem Based Learning sebesar 84.36 dan rerata model pembelajaran Group Investigation sebesar 67.81, maka dapat ditarik sebuah kesimpulan bahwa model pembelajaran Problem Based Learning lebih efektif dibandingkan model pembelajaran Group Investigation dalam menghasilkan prestasi belajar IPA.

Nilai $F_{b}$ sebesar 0.59 dengan daerah kritis 7.31 . $F_{b}$ tidak terletak pada daerah kritis sehingga $\mathrm{H}_{0 \mathrm{~A}}$ diterima. Diterimanya $\mathrm{H}_{\mathrm{OA}}$ mengindikasikan bahwa diantara kecerdasan interpersonal tinggi dan kecerdasan interpersonal rendah memberikan efek yang tidak berbeda dalam menghasilkan prestasi belajar IPA. Hal ini berarti tidak ada pengaruh antara kecerdasan interpersonal tinggi dan rendah dalam menghasilkan prestasi belajar IPA.

Nilai $F_{c}$ sebesar 0.036 dengan daerah kritis 7.31. $F_{c}$ tidak terletak pada daerah kritis sehingga $H_{0 B}$ diterima. Diterimanya $\mathrm{H}_{\mathrm{OB}}$ mengindikasikan bahwa diantara model pembelajaran baik model pembelajaran Problem Based Learning maupun model pembelajaran Group Investigation dan kecerdasan interpersonal baik kecerdasan interpersonal tinggi maupun kecerdasan interpersonal rendah memberikan efek yang terhadap prestasi belajar IPA. Hal ini berarti tidak ada interaksi pengaruh antara model pembelajaran dan kecerdasan interpersonal dalam menghasilkan prestasi belajar IPA.

Karena tidak ada interaksi pengaruh antara model pembelajaran dan kecerdasan inter-personal maka perbandingan antara model pembelajaran Problem Based Learning dan Group Investigation untuk setiap kecerdasan interpersonal, baik kecerdasan interpersonal tinggi maupun kecerdasan interpersonal rendah mengikuti perbandingan marginalnya. Dengan memperhatikan rerata masingmasing sel dan rerata marginalnya dapat disimpulkan bahwa model pembelajaran Problem Based Learning lebih efektif dibandingkan model pembelajaran Group Investigation baik pada kecerdasan interpersonal tinggi ataupun kecerdasan interpersonal rendah.

\section{PEMBAHASAN}

Secara rinci pembahasan hasil penelitian dan pengujian hipotesis altrnatif tersebut dapat diuraikan sebagai berikut ini: 


\section{Pengaruh Model Pembelajaran Problem Based Learning dan Group Investigation terhadap Prestasi Belajar IPA ditinjau dari Kecerdasan Interpersonal}

Berdasarkan kesimpulan hasil analisis variansi dua jalan dengan sel tak sama mengatakan bahwa $\mathrm{H}_{0}$ ditolak, sehingga hipotesis pertama dalam penelitian ini diterima. Dengan demikian hasil penelitian ini menunjukkan bahwa ada pengaruh positif antara penerapan model pembelajaran Problem Based Learning dan Group Investigation terhadap prestasi belajar IPA pada peserta didik kelas V SDN Ngringo sedabin Diponegoro Kecamatan Jaten Kabupaten Karanganyar.

Penelitian ini membuktikan bahwa dalam pembelajaran IPA di SD model pembelajaran Problem Based Learning dibandingkan dengan model pembelajaran Group Investigation dengan memperhatikan reratanya, maka model pembelajaran Problem Based Learning lebih efektif dibandingkan dengan model pembelajaran Group Investigation. Perhitungan rerata menunjukkan bahwa rerata model pembelajaran Problem Based Learning sebesar 84.36 dan rerata model pembelajaran Group Investigation sebesar 67.81. Sejalan dengan diterimanya hipotesa pertama ini menurut Sugiyanto (2009) Problem Based Learning mengambil psikologi kognitif sebagai dukungan teoritisnya. Fokus utama Problem Based Learning tidak banyak pada apa yang sedang dikerjakan peserta didik (perilaku peserta didik), namun lebih menekankan kepada apa yang dipikirkan oleh peserta didik (tingkat kognisi peserta didik) selama melaksanakan kegiatan pembelajaran dengan model pembelajaran Problem Based Learning. Hal ini sangat erat kaitannya dengan konsep belajar berdasarkan pandangan teori konstruktivisme, dimana belajar pada peserta didik adalah ketik mereka mampu membangun pengetahuan mereka sendiri di dalam benaknya. Dalam pembelajarannya, menurut Sugiyanto (2009) Problem Based Learning tidak banyak memfokuskan pada apa yang dikerjakan siswa (perilaku mereka) tetapi pada apa yang siswa pikirkan (kognisi mereka) selama mereka mengerjakan. Model pembelajaran Problem Based Learning merangsang peserta didik untuk menganalisis masalah, memperkirakan jawaban-jawabannya, mencari data, menganalisis data dan menyimpulkan jawaban terhadap masalah (Mudjiman, 2011). Semua proses tersebut terjadi dalam ranah kognisi peserta didik. Peserta didik diharapkan mampu mengoptimalkan kemampuan kognitifnya untuk dapat menyelesaikan masalah yang diberikan guru. Siswa membentuk pengetahuannya melalui sebuah masalah yang disuguhkan padanya.

Dalam pembelajaran Group Investigation menurut Sudjana (2010) model pembelajaran kooperatif Group Investigation lebih menekankan pengembangan kemampuan memecahkan permasalahan dalam suasana yang demokratis, dimana pengetahuan tidak diajarkan secara langsung kepada peserta didik, tetapi diperoleh melaui proses pemecahan masalah. Model pembelajaran Group Investigation terdiri dari beberapa topik-topik kajian. Setiap kelompok yang akan melaksanakan pembelajaran ini berhak memilih salah satu topik yang telah disediakan oleh guru. Kemudian setiap ketua tim membagi topik-topik menjadi tugas-tugas pribadi anggota kelompoknya dan melakukan kegiatan yang diperlukan untuk mempersiapkan laporan kelompok. Tiap anggota kelompok kemudian mempresentasikan penemuan mereka di depan kelas. Model pembelajaran ini sebenarnya lebih menarik perhatian peserta didik, di samping fokus kajian materi yang akan diselesaikan pada kegiatan investigasi kelompok, mereka juga diberikan kesempatan lebih dalam pelaksanaan presentasi di depan kelas dalam suasana yang demokratis.

Kedua model pembelajaran ini sama-sama menerapkan metode pemecahan masalah. Hanya saja yang membedakan diantara keduanya adalah jika Problem Based Learning tidak membagi kajian materi yang perlu dipecahkan ke dalam unit-unit tertentu, sedangkan Group Investigation membagi ke dalam topik-topik tertentu sesuai dengan kajian materinya. Dengan begitu pada model pembelajaran Problem Based Learning lebih memberikan kesempatan yang lebih luas kepada peserta didik untuk mengaktualisasikan ranah kognitifnya. Tidak menutup kemungkinan, pada model pembelajaran Group Investigation memiliki keunggulan dalam fokus terhadap kajian permasalahan yang dikaji dengan kegiatan investigasi kelompoknya.

\section{Pengaruh Kecerdasan Inter-personal Tinggi dan Rendah terhadap Prestasi Belajar IPA}


Berdasarkan kesimpulan hasil analisis variansi dua jalan dengan sel tak sama mengatakan bahwa $\mathrm{H}_{\mathrm{OA}}$ ditolak, sehingga hipotesis kedua dalam penelitian ini ditolak. Dengan demikian hasil penelitian ini menunjukkan tidak ada pengaruh antara kecerdasn interpersonal terhadap prestasi belajar IPA. Diterimanya $\mathrm{H}_{\mathrm{OA}}$ mengindikasikan bahwa baik kecerdasan intrepersonal tinggi maupun rendah tidak memberikan efek yang sama dalam menghasilkan prestasi belajar IPA.

Menurut Yaumi (2012) kecerdasan interpersonal sangat berhubungan dengan konsep interaksi dengan orang lain di sekitar. Interaksi yang dimaksud bukan hanya sekedar berhubungan biasa saja seperti berdiskusi dan membagi suka dan duka, melainkan juga memahami pikiran, perasaan dan kemampuan untuk memberikan impati dan respon. Biasanya orang yang memiliki kecerdasan interpersonal tinggi ini memiliki sikap sangat sensitif terhadap suasana hati dan perasaan orang lain. Empat elemen penting menurut Yaumi (Mork, 2011) dari kecerdasan interpersonal yang perlu digunakan dalam membangun komunikasi, mencakup: (1) membaca isyarat sosial, (2) memberikan empati, (3) mengontrol emosi, serta (4) mengekspresikan emosi pada tempatnya.

Berdasarkan definisi mengenai kecerdasan interpersonal di atas, pada pembelajaran IPA pada kelas eksperimen, peserta didik yang memiliki kecerdasan interpersonal rendah ternyata mampu menghasilkan prestasi belajar IPA yang lebih tinggi dibandingkan dengan peserta didik yang memiliki kecerdasan interpersonal tinggi, baik pada model pembelajaran Problem Based Learning maupun model pembelajaran Group Investigation.

\section{Pengaruh Interaksi antara Model Pembelajaran dengan Kecerdasan Interpersonal terhadap Prestasi Belajar IPA}

Kesimpulan dari hipotesis yang ketiga adalah $\mathrm{H}_{0 \mathrm{~B}}$ diterima. Hal ini berarti tidak ada interaksi pengaruh antara model pembelajaran baik model pembelajaran Problem Based Learning dan Group Investigation maupun kecerdasan interpersonal baik tinggi maupun rendah terhadap prestasi belajar IPA.

\section{SIMPULAN DAN SARAN}

\section{Kesimpulan}

1. Terdapat pengaruh yang signifikan antara penerapan model pembelajaran Problem Based Learning dan Group Investigation terhadap prestasi belajar IPA siswa kelas V Sekolah Dasar Negeri sedabin Diponegoro Ngringo Jaten Karanganyar tahun pelajaran 2013/ 2014.

2. Tidak terdapat perbedaan pengaruh yang signifikan antara siswa yang memiliki kecerdasan interpersonal tinggi dan kecerdasan inter-personal rendah terhadap prestasi belajar IPA siswa kelas V Sekolah Dasar Negeri di Dabin Diponegoro Ngringo Jaten Karanganyar tahun pelajaran 2013/2014.

3. Tidak terdapat interaksi pengaruh yang signifikan antara model pembelajaran Problem Based Learning maupun Group Investigation dan kecerdasan inter-personal, baik kecerdasan interpersonal tinggi maupun kecerdasan interpersonal rendah dalam menghasilkan prestasi belajar IPA siswa kelas V Sekolah Dasar Negeri di Dabin Diponegoro Ngringo Jaten Karanganyar tahun pelajaran 2013/2014.

\section{Saran}

Berdasarkan simpulan dan implikasi di atas, maka ada beberapa saran yang dapat disampaikan diantaranya:

\section{Bagi Guru}

a. Guru dapat memilih model pembelajaran yang sesuai dengan tujuan pembelajaran agar pembelajaran berjalan secara optimal sehingga menghasilkan prestasi belajar yang baik. 
b. Peran serta guru dalam proses pembelajaran yang menggunakan sistem penyelesaian masalah merupakan peran yang cukup membantu peserta didik, bukan peran utama. Dalam hal ini peran guru sebagai motivator dan evaluator.

2. Bagi Peserta Didik

a. Peserta didik sebaiknya mulai menumbuhkan kebiasaan belajar mandiri, dimana kemandirian dalam belajar merupakan konsep awal munculnya model pembelajaran Problem Based Learning.

b. Diharapkan peserta didik memiliki kemampuan membangun komunikasi efektif dalam pembelajaran yang bersifat membutuhkan penyelesaiajn secara berkelompok.

\section{Bagi Sekolah}

a. Sekolah sebaiknya lebih memberikan dukungan terhadap kemajuan prestasi belajar peserta didik baik secara pemenuhan sarana dan prasarana.

b. Sekolah diharapkan kesempatan lebih dalam memberikan kesempatan guru dalam mengikuti pelatihan-pelatihan model pembelajaran yang inovatif.

\section{Bagi Peneliti Lain}

Bagi para peneliti lain diharapkan dapat mengembangkan penelitian ini dengan penelitianpenelitian sejenis dengan materi pelajaran yang lain pula sehingga dapat dilaksanakan secara luas.

\section{DAFTAR PUSTAKA}

Anitah, S. (2009). Teknologi Pembelajaran. Surakarta: Yuma Pustaka.

Azwar, S. (2013). Tes Prestasi. Yogyakarta: Pustaka Pelajar.

. (2013). Pengantar Psikologi Inteligensi. Yogyakarta: Pustaka Pelajar.

. (2013). Metode Penelitian. Yogyakarta: Pustaka Pelajar.

Mudjiman, H. (2012). Belajar Mandiri Pembekalan dan Penerapan. Surakarta: UNS Press.

Purwanto. (2011). Evaluasi Hasil Belajar. Yogyakarta: Pustaka Belajar.

Slavin, R. (2005). Cooperative Learning: theory, Research, and Practise. Bandung: Penerbit Nusa Media.

Sugiyanto. (2009). Model-model Pembelajaran Inovatif. Surakarta: Panitia Sertifikasi Guru Rayon 13 FKIP UNS Surakarta.

Trianto. (2007). Model-model Pembelajaran Inovatif Berorientasi Konstruktivistik. Jakarta: Prestasi Pustaka.

Yaumi, M. (2012). Pembelajaran Berbasis Multiple Intelligences. Jakarta: PT. Dian Rakyat. 